\title{
Wildfire risk and its perception in Kabylia (Algeria)
}

\author{
Ouahiba Sahar ${ }^{(1)}$, \\ Vittorio Leone ${ }^{(2)}$, \\ Hanane Limani ${ }^{(1-3)}$, \\ Naima Rabia ${ }^{(1)}$, \\ Rachid Meddour ${ }^{(1)}$
}

\begin{abstract}
This research aims to study wildfire perception by residents living in Wildland Urban Interface (WUI) in Kabylia (Algeria). We conducted an exploratory qualitative survey contacting 254 randomly selected individuals in eight hamlets of the Mizrana forest. Face-to-face questionnaires were administered to understand the fire risk problem. Respondents think that their homes are not exposed to fire risk and perceive their hamlets are protected against wildfires; on the contrary, they perceive their property (fields, livestock, olive trees, etc.) as exposed to fire risk. The vast majority of respondents declare to know how to defend themselves in the case of a fire event, using water and hand tools. Residents mainly use fire for stubble burning and disposal of domestic waste. Their skill in using fire as a land management tool respectively comes from their fathers, grandfathers and mothers. Results show the necessity of making resident more aware of the risks that wildfires pose to them. A culture of risk needs to be developed within the territory to limit vulnerability and the likelihood of destructive fires.
\end{abstract}

Keywords: Algeria, Fire Use, Mizrana Forest, Risk Perception, TEK, Wildland Urban Interface, Wildfire

\begin{abstract}
Introduction
A marked increase in the number of wildfires, which are very frequent in the five Southern member States of European Union is currently registered also in the Southern Mediterranean rim, namely in Tunisia, Morocco, Lebanon (European Commission 2015), and above all in Algeria (MeddourSahar 2015), hitherto considered with a low fire incidence level (Alexandrian et al. 1999). Forests cover approximately 3.7 million hectares (only $1.5 \%$ of the land area) in Algeria, half of which are degraded forest or maquis (Pswarayi-Riddihough 2002), concentrated in some wilayas (provinces) of the Northern part of the country, with a negative gradient East-West. Algerian forests are currently in a critical state (DGF 2004) due to human activities (MeddourSahar 2014), which add a negative impact to the extreme climatic factors of the country (heat waves in combination with drought - Duguy et al. 2013, Cardil et al. 2014, Gouveia et al. 2016). Fire, extensive
\end{abstract}

livestock breeding, overgrazing, clearing, illegal forest harvesting, and urbanization contribute to forest degradation.

The most recent available statistical data (1985 to 2014) report an average of 1,912 fires and 36,205 hectares of area burned annually, rather exclusively as a result of negligent or malicious anthropic activities (Meddour-Sahar 2015). The number of wildfires exhibits an increasing trend, whereas burned surfaces follow a rather stable or slightly decreasing one.

Notwithstanding the importance of wildfire phenomenon, which strongly affects densely inhabited areas with high levels of damage and frequent life loss (MeddourSahar et al. 2013a), Algeria has a scarce presence in the current international wildfire literature, mainly dealing with post fire regeneration and remote sensing (Rashid 1987, Meddour 1992, Ouelmouhoub \& Benhouhou 2007, Bekdouche et al. 2008, Guettouche et al. 2011, Slimani et al. 2014, Belkaid 2016). Recent research papers (Med-
(1) Department of Agricultural Sciences. University of Mouloud Mammeri, Box 17 RP, Tizi Ouzou 15000 (Algeria); (2) formerly at Department of Crop Systems, Forestry and Environmental Sciences, University of Basilicata, v.le dell’ Ateneo Lucano 10, 85100 Potenza (Italy); (3) Biodiversity Ecology Evolution, University of Montpellier (France)

@ Ouahiba Sahar (o.sahar@yahoo.fr)

Received: Jul 02, 2017 - Accepted: Feb 12, 2018

Citation: Sahar O, Leone V, Limani H, Rabia N, Meddour R (2018). Wildfire risk and its perception in Kabylia (Algeria). iForest 11: 367-373. - doi: 10.3832/ifor2546-011 [online 2018-05-04]

Communicated by: Matteo Garbarino
dour-Sahar et al. 2013a, 2013b, Meddour-Sahar \& Bouisset 2013, Meddour-Sahar 2014) have examined the causes of wildfires and the organization of the institutional fire fighting apparatus. No reference exists, according to our knowledge, about the perception of wildfires by residents; however, this kind of research is almost absent also in the countries of the Northern Mediterranean rim (FAO 2006, Langer \& McGee 2017). Hence, our interest was to carry out a first exploratory analysis about perceptions of wildfire risk associated with living in or near the forested area of the Mizrana forest, considered well representative of the most general conditions of Kabylia.

In Mizrana, most fires are linked to rural habitats scattered along the roads, which generate consumption of space and other problems, such as the use of fire for the disposal of household refuse. They are the result of an unplanned urban sprawl, that allows individuals to build close to vegetation or even to embed their houses within it, thus settling in harms' way, since the link between fires and urban spaces in proximity of forests is more than a hypothesis (Chuvieco et al. 1999, Velez 2000, Catry et al. 2007, Ganteaume et al. 2013).

The factors that increase fire risk (e.g., structure and type of vegetation, its proximity to house, lack of defensible space) are the very elements that satisfy the search of amenity by new residents and represent what they appreciate within the landscapes in which they have decided to reside. Building homes at risk of wildfires because they like being surrounded by trees, can be defined as "amenity risk" (Berger et al. 2008, Kousky et al. 2006). 


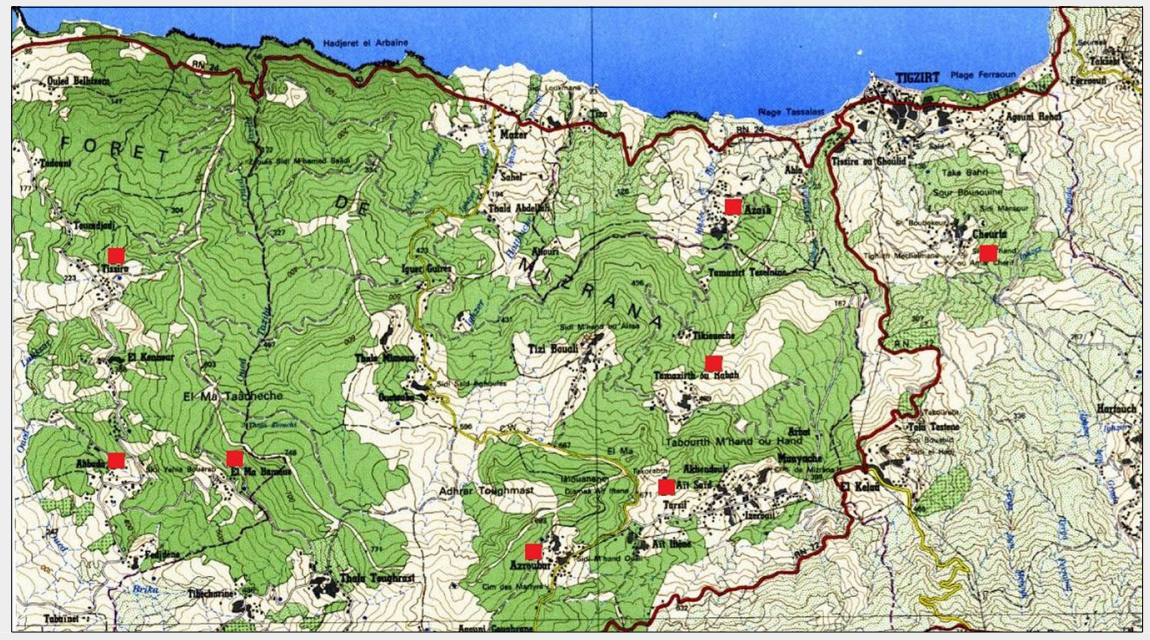

Fig. 1 - Excerpt of the topographic map 1:50.000. Green areas represent the Forest of Mizrana, in the wilayas of Tizi Ouzou and Boumerdes (Algeria). Hamlets (represented by red squares) are mainly located along roads or close to the forest edge.

\section{Material and methods}

\section{Study area}

The study area is represented by the domanial natural forest of Mizrana (2,233 ha), located in the low elevation coastal area of Kabylia (Fig. 1).

The climate is a subhumid Mediterranean type, with temperate variation. The vegetation is represented by cork oak (Quercus suber L.) stands, whose undergrowth is dominated by Arbutus unedo L., Erica arborea L., Rubus ulmifolius Schott, Myrtus communis L. and Phillyrea media L.

The Mizrana forest is subject to harmful practices and has been affected by recurrent wildfires; during the period 1988-2013, 113 fires burned an area of 2,036 ha (Hamel 2016). Fires can be explained, among oth ers, by the elimination of the forest to recover spaces to be built, as already shown for Spain by Gonzalez (2007) and for Greece by Bassi \& Kettunen (2008).

The study area is densely inhabited (up to 287 habitants $\mathrm{km}^{-2}$ ) with the population distributed in clusters of hamlets near the forested areas, or close to their edges.

Traditional agriculture still occupies an important place in Kabylia: it is based on breeding (sheep, cattle and goats), arboriculture (olive and fig trees) and vegetable crops. The vast majority of farms in the study area have a surface of at most one hectare. People mainly rely upon low-income subsistence agriculture, in which they focus on growing food to feed themselves and their families, with little or no surplus for trade. This type of agriculture dramatically exposes the family to poverty, should a wildfire destroy their crops.

\section{Methods}

The survey was carried out in eight hamlets in the domanial forest of Mizrana, belonging to three rural municipalities (Baladiah): Tigzirt (located near the coast), Mizrana and Afir (in the inner part, respectively about 6.50 and $5.20 \mathrm{~km}$ away; Mizrana is in the core of the forest), as representative of the wilayas of Tizi Ouzou and Boumerdes, which are among the most severely fire affected wilayas in the country (Meddour-Sahar \& Derridj 2010, MeddourSahar 2014). Two of the three Baladiah (Tigzirt and Mizrana) are at high or extreme risk of wildfires (Meddour-Sahar \& Derridj 2010, Meddour-Sahar 2014), given the values of their RMA (see below), whereas in the hamlet of Afir the risk is average. RMA is the average annual risk RMA $=\mathrm{SMA} \times 100$ I SCM, where SMA is the average area burned per year (ha) and SCM is the current forest area (ha - De Montgolfier 1989, Peyre 2001).

The total population of the three municipalities is 34,673 people and they encom-

Tab. 1 - The most relevant socio-economic indicators for the study areas.

\begin{tabular}{lccc}
\hline Indicator/Baladiah & Mizrana & Tigzirt & Afir \\
\hline Population density (no. $\mathrm{km}^{-2}$ ) & 168 & 287 & 213 \\
Forest land (ha) & 3595 & 2235 & 1400 \\
Forestry ratio (\%) & 72.00 & 36.05 & 22.58 \\
Agricultural land (ha) & 959 & 973 & 1.820 \\
Total livestock (no.) & 8783 & 4454 & 6811 \\
Livestock (no. km ${ }^{-2}$ ) & 152 & 107 & 110 \\
RMA (annual mean fire risk) & 3.19 & 10.69 & 1.08 \\
& High (2-4) & Extreme $(>8)$ & Average (1 - 2) \\
\hline
\end{tabular}

pass a total of 63 hamlets; the choice of the eight hamlets therefore gave a sampling rate of $12.7 \%$. In Tab. 1 the basic geographic and socio-economic indicators of the study area are presented.

The study area represents an intermix type of WUI (Wildland/Urban Interface), i.e., areas undergoing a transition from agricultural and forest uses to urban land uses, respectively Types 7, 8, 9 (dense clustered) according to Lampin-Maillet et al. (2010).

Our survey was conducted between March and May 2016, by distributing purposely prepared questionnaires (see Appendix 1) during a face-to-face interview, i.e., having direct contact with each respondent. We discarded as unfeasible other methods for administering the questionnaires, e.g., by mail or e-mail, due to problems of illiteracy and the lack of Internet connection, respectively.

Local contacts were activated long before starting the field work, to obtain the acceptance of the initiative. Without this crucial step, we could not have reduced the bias, diffidence and the potential aversion of rural people towards the surveyors. This partly explains the slightly different numbers of respondents within each hamlet.

The questionnaire used simple, and unambiguous words. It was a closed-ended or fixed-item type; questions were multiplechoice with unordered response choices. The questionnaire was structured in five sections:

1. demographic information;

2. agro-forestry activities;

3. knowledge about fires;

4.risk perception by the population and their degree of concern;

5. use of fire by the population.

Data were processed using Sphin ${ }^{\circledR}$ plus $V_{5}$ survey and statistical software (http:// www.lesphinx-developpement.fr). For the identification of a structure in the dataset obtained from questionnaires, we used a biplot resulting from a Factorial Correspondence Analysis (FCA), i.e., a low-dimensional display of the data matrix where data in rows and columns in a contingency table are represented. FCA is an excellent 2D approximation of the hierarchy of the relationships between rows and columns of contingency tables.

\section{Demographic information and agro- forestry activities}

The target population for the survey consists of 254 individuals, aged 15 years and older, of which 118 women and 136 men, $46 \%$ and $54 \%$, respectively (Tab. 2). The relatively high presence of women reflects the matriarchal society of Kabilia (Grassof 2003) and their direct involvement in agricultural activities.

The dominant age classes are 20-39 and 40-59. Age $>60$ accounts for $21 \%$. Thirty percent of respondents are housewives, followed by employees and students, with 
Tab. 2 - Demography of sampled hamlets.

\begin{tabular}{|c|c|c|c|c|c|c|c|c|c|c|}
\hline \multirow[b]{2}{*}{ Class } & \multirow{2}{*}{$\begin{array}{l}\text { Baladiah (Town) } \\
\text { Hamlets }\end{array}$} & \multicolumn{2}{|l|}{ Afir } & \multicolumn{3}{|c|}{ Mizrana } & \multicolumn{3}{|c|}{ Tigzirt } & \multirow[t]{2}{*}{ Total } \\
\hline & & Abada & Tissira & $\begin{array}{c}\text { Alma } \\
\text { N'waman }\end{array}$ & Azroubar & Ait Said & $\begin{array}{l}\text { Tamazirt } \\
\text { Ourabah }\end{array}$ & Cheurfa & El Azaib & \\
\hline \multirow{2}{*}{ Gender } & Men & 12 & 14 & 23 & 17 & 18 & 15 & 14 & 23 & 136 \\
\hline & Women & 13 & 11 & 19 & 13 & 17 & 14 & 15 & 16 & 118 \\
\hline \multirow[t]{5}{*}{ Age } & Less than 20 & 0 & 1 & 3 & 0 & 3 & 0 & 1 & 4 & 12 \\
\hline & $20-39$ & 14 & 9 & 15 & 13 & 13 & 12 & 11 & 17 & 104 \\
\hline & $40-59$ & 7 & 11 & 15 & 9 & 7 & 9 & 11 & 14 & 83 \\
\hline & $60-79$ & 4 & 3 & 9 & 5 & 8 & 8 & 6 & 4 & 47 \\
\hline & $>80$ & 0 & 1 & 0 & 3 & 4 & 0 & 0 & 0 & 8 \\
\hline \multirow[t]{8}{*}{ Employement } & Farmer & 1 & 4 & 7 & 4 & 4 & 3 & 3 & 3 & 29 \\
\hline & Housewife & 8 & 10 & 9 & 6 & 10 & 9 & 13 & 12 & 77 \\
\hline & Liberal & 3 & 0 & 5 & 5 & 3 & 2 & 0 & 2 & 20 \\
\hline & Official & 4 & 6 & 10 & 5 & 7 & 6 & 4 & 8 & 50 \\
\hline & Retired & 2 & 2 & 3 & 2 & 2 & 2 & 1 & 4 & 18 \\
\hline & Shepherd & 0 & 0 & 1 & 2 & 1 & 1 & 3 & 2 & 10 \\
\hline & Student & 4 & 3 & 3 & 2 & 6 & 4 & 3 & 8 & 33 \\
\hline & Unemployed & 3 & 0 & 4 & 4 & 2 & 2 & 2 & 0 & 17 \\
\hline Total & - & 25 & 25 & 42 & 30 & 35 & 29 & 29 & 39 & 254 \\
\hline
\end{tabular}

$20 \%$ and $13 \%$ respectively, and farmers with $11 \%$; unemployed and retired respondents are a minority (14\% of the total); sheep farmers and breeders represent only $4 \%$ of the sample. The concerned communities reflect a traditional society, currently dependent on activities in the tertiary sector, since its members work in towns but live in the countryside.

Seventy-six percent of the respondents have lived in the study area since birth, and $11 \%$ have inhabited there for more than 20 years. The main activities (more than 30\%) are gardening, growing fruit trees and cattle (sheep, goats) breeding. Employment in the nearby forest was declared by only 2 respondents.

The number of stock units is low for all types of species (cattle, sheep, goats): the modal class is 0-5 stock units, thus confirming a subsistence activity. Livestock is mainly fed with a mixed regime, fodder and grazing in forest $(74.8 \%)$ or fed with fodder (21.5\%). Products, in general, are mainly for self-consumption (65.1\%).

\section{Results and discussion}

\section{Knowledge about fires}

Concerning the trend in fire occurrence, the sample is strongly divided: $28.3 \%$ declare it is constant, $61.4 \%$ perceive a decrease and only $10.2 \%$ consider it to be increasing.

Regarding the situation of forest fires, $78.4 \%$ of respondents declare to be aware of the fire situation in their hamlets, and $79.5 \%$ have already witnessed forest fires. Forest fires with less than 1 hectare of burned area have been directly witnessed by $52 \%$ of respondents, whereas $38.2 \%$ of them have directly witnessed medium size fires of less than 50 hectares. Less than $9.8 \%$ of respondents have directly witnessed large fires ( $>100$ hectares).

In the assessment of damages, $35.7 \%$ of respondents report damages to the forest and wood or fodder, followed by fields (32.5\%) and fruit trees (19.2\%). Fewer respondents report damage to houses and to herds ( $2.1 \%$ and $7.7 \%$, respectively), and loss of life (2.8\%), the latter referred to by only two hamlets (Alma N'waman and Tissira).

\section{Risk perception}

A vast majority (76.8\%) of respondents perceive that their hamlets are well protected against forest fires. Their philosophy of prevention is based on tracks, firebreaks and water reserves, designed within the framework of traditional management projects (FAO 2006). In decreasing order, the preference in terms of prevention infrastructures is: $75.2 \%$ for tracks; $61 \%$ for water points; $40.2 \%$ for firebreaks. The vast majority (98\%) of respondents consider no other means to protect themselves from fires.

The perception of fires as a threat is rather low at only $16.1 \%$ of respondents, whereas there is larger consensus of respondents that fear fires (55.5\%) or that are greatly concerned of them (28.3\%). Reasons of concern are rather different, with $23.9 \%$ claiming that fire is a constant threat for them and their assets; $25.6 \%$ of respondents point out the insufficient fire fighting service provided by the Civil Protection agency, or its late intervention in case of a fire (16\%), and the relatively long distances between the cities and the locations of the fires (10\%), which reflects on the time of arrival and first intervention. Some respondents (13.6\%, the majority from the hamlet of Abada) are concerned by political fires (to oppose terrorism - Fig. 2).

\section{Information about risk}

A vast majority of respondents (85\%) declare their interest in receiving more information about wildfire risk, mainly under the form of meetings (39.8\%), pamphlets
(22.9\%) and radio broadcasts (22.3\%). On the contrary, daily news and television are by far the less preferred ( $8.2 \%$ and $6.8 \%$, respectively).

Radio broadcasts and meetings are the most preferred means by people in the age class from 40-59 to 60-79, whereas younger respondents (age class 20-39) clearly prefer pamphlets and radio broadcasts. Meetings, which are also an occasion for socialization, are the media preferred by the oldest participants (age $>80$ ).

Social groups confirm their scattered preference: radio attracts housewives, meetings are appreciated by the retired, newspapers are preferred by the liberal and unemployed, pamphlets by students, television by farmers and officials. Like housewives, shepherds prefer meetings.

\section{Information source}

Foresters are indicated by the vast majority of respondents (60.5\%) as the preferred source of information, followed by municipalities (26\%), Civil Protection and Firefighters (13.5\%).

On the contrary, in case of fire the vast majority (95.7\%) of respondents will call the fire service. This may just indicate that the emergency telephone number of the fire service (14) is much easier to remember than the foresters' one, which has a nonfriendly nine digits format.

\section{Fire hazard and assets}

The vast majority of respondents (69.3\%) think that their homes are not exposed to the risk of fire, thus aligning to the previous $76.8 \%$ of surveyed people who perceive their hamlets well protected.

At the same time, $68.5 \%$ of respondents believe that their property (fields, livestock, olive trees, etc.) is exposed to fire risk. Assets such as fields and crops are considered the most exposed to fire risk (57.8\%), followed by olive trees (26\%), and 


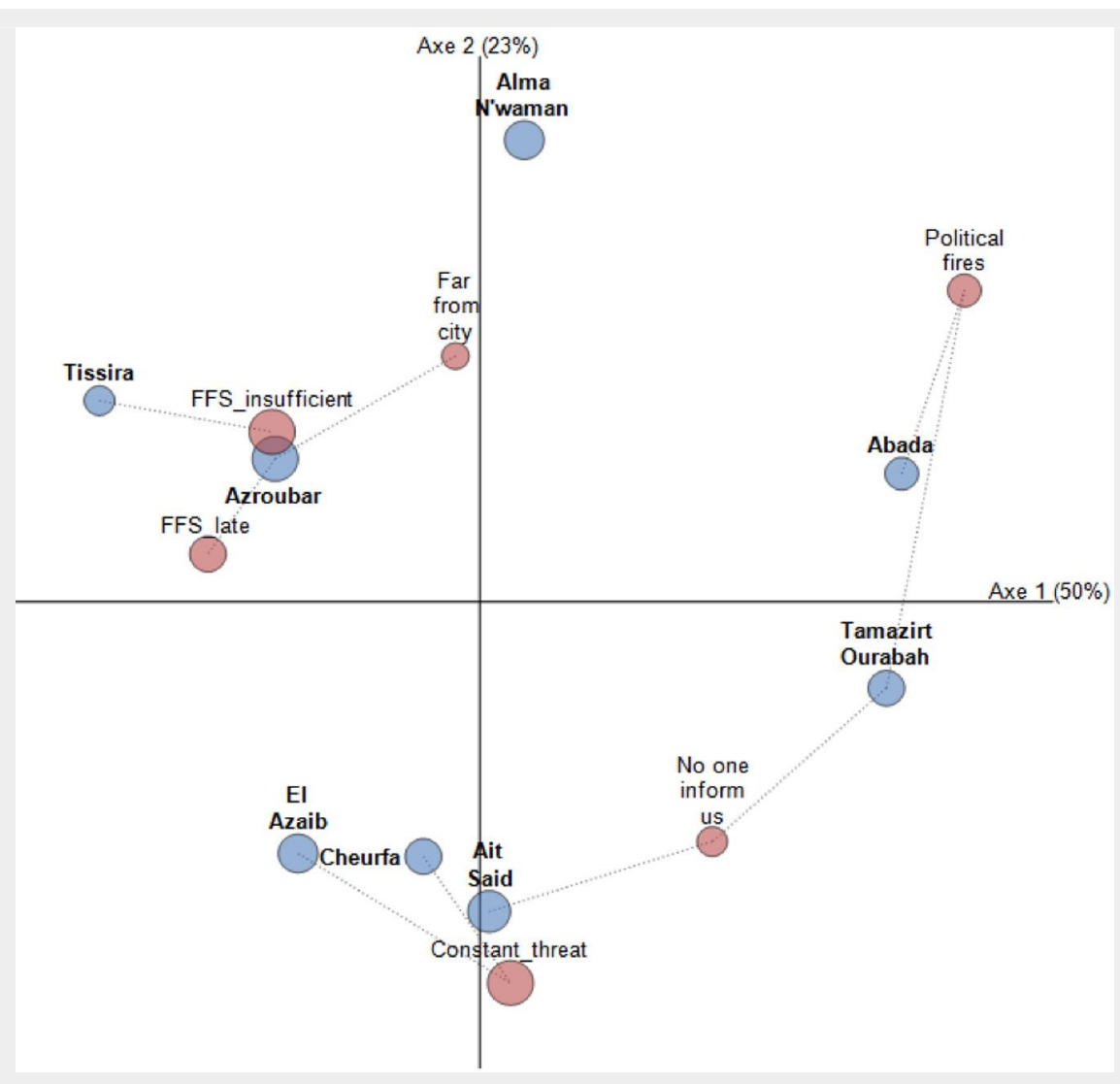

Fig. 2 - Fire concern in the different hamlets based on Factorial Correspondence Analysis (FCA). The diameter of circles is proportional to values in the contingency table, while dotted lines join the hamlets (blue circles) sharing a specific problem (red circles). For the hamlets of El Azaib, Ait Said, Cheurfa fire is a constant threat; in the hamlet of Abada there are concerns of political fires; Azrouba and Alma N'waman complain about the relative inefficiency and late arrival of Civil Protection forces, and distance from town (Chi square $=156.95 ; \mathrm{df}=35 ; \mathrm{p}<0.01$ ).

livestock (16.3\%). Respondents focus risk more on their productive assets than on buildings, which are probably considered safer, due to their incombustible building materials (mainly stones and bricks).

\section{How to defend against fires}

The quasi-totality of respondents $(92.1 \%)$ declare to know how to defend themselves in case of fire events; in decreasing order, the tools to be utilized are water (42.4\%), and hand tools (39.3\% - Fig. 3). The use of backfire (i.e., a fire that burns into or against the wind, purposely set to con- sume fuel before the arrival of an advancing wildfire), is mentioned by only $13.9 \%$ of respondents. An even smaller number of respondents mention perimetral strips, to be ploughed up by a tractor around cultivated fields.

Use of water is the most preferred technique for all groups, but especially by housewives (32.2\%), employees (19.3\%), students (12.9\%), and farmers (10.9\%).This probably depends on its use by firemen, and the popularity of images of firefighting interventions. In any case, it contrasts with the water paucity which characterizes the hamlets and the whole country, and with the lack of pumps, hoses or tractors.

The use of backfire, on the contrary, is rather equally shared by a minority of respondents, with the exception of breeders; probably, for the latter group, this technique might appear dangerous to livestock and to fodder resources. Although rather modest, this preference is probably connected to the traditional habit of using fire in land management (the keçir) "...that consisted of clearing land by setting controlled fires every four years..." (Ford 2008, pag.4).

Back-fire could be considered as a telltale sign of persistence of TEK, Traditional Ecological Knowledge (Berkes et al. 2000), which encompasses knowledge about the environment derived from experience and traditions (Usher 2000, Houde 2007, USFWS 2017).

\section{Prevention measures}

Among the prevention measures already used by $90.6 \%$ of respondents, the majority state that they use brush clearing around houses (70\%), followed by pruning trees closest to their homes (16.4\%), and ploughed strips around their fields (13.6\%). This latter modest value is rather significant, because the Decree 87- 44 of 10 February 1987 sets rules imposing the presence of defensive strips around all fields; the declared non-compliance with laws by about $86 \%$ of respondents contrasts the feeling of being well defended against fire.

Measures mentioned have a different efficacy: whereas brush clearing around houses, if wide enough, creates a defensible space, where fire spread could be easily stopped, pruning of trees is only efficacious to reduce the possibility that a running fire may become a crown fire, and has no effect on preventing or mitigating surface fires (Corona et al. 2015).

The low preference for perimetral ploughed strips, on the contrary, besides being a failure to comply with specific rules for the protection of domanial forests, is an aggravating factor of risk, since it makes easier for fires to propagate on cultivated land, so producing a disaster in a local economy grounded on subsistence.

From the perspective of the single hamlets, the preferences for prevention mea-

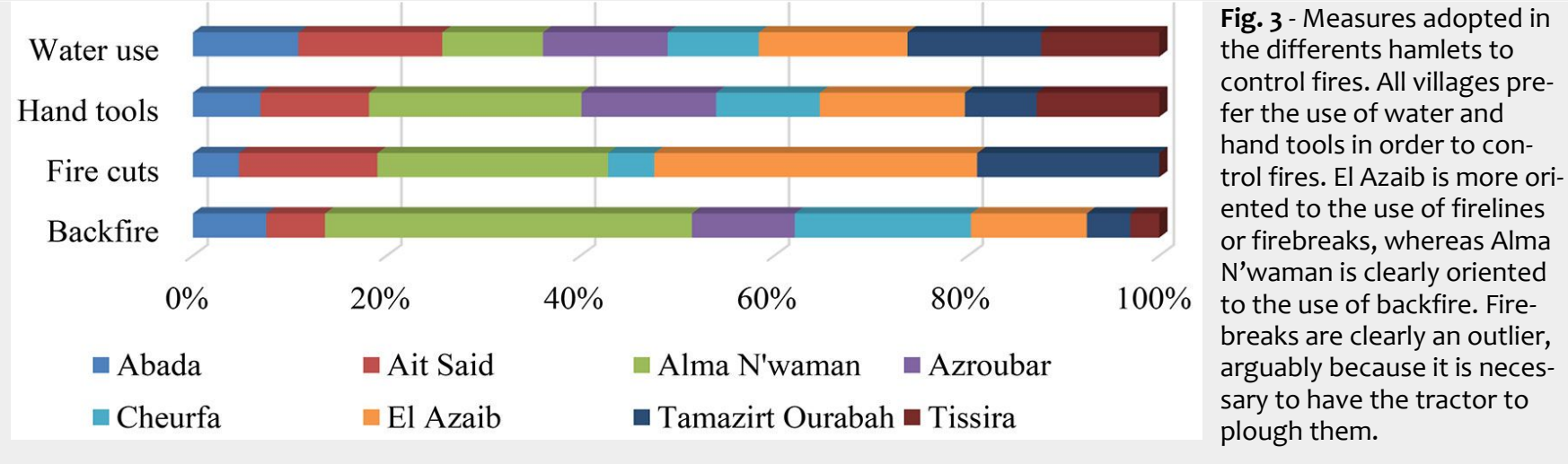


Wild honey harvesting

\title{
Weed burning
}

Stubble burning

Pasture renewal

Land clearing

Bee-hives fumigation

Burning agricultural residues

Burning household waste

\author{
Brush clearing
}

$0 \%$

$$
10 \% \quad 20 \%
$$

$40 \%$

$50 \%$

$60 \%$

$70 \%$

$80 \%$

$90 \%$

$100 \%$

abada

Ait Said

alma N'waman

घzroubar

- Cheurfa

al Azaib

- Tamazirt Ourabah

- Tissira

Fig. 4 - Distribution of fire use in the different hamlets. In Azroubar, Abada, Ait Said, Tamazirt Ourabah fire use appears strictly connected with stubble burning, disposal of domestic waste, and mainly for Azroubar, weed burning. Respondents from Tissira favour land clearing, burning agricultural residues, and wild honey hunting. Fumigation of bee-hives seems only restricted to Cheurfa and El Azaib, together with brush clearing. Respondents from Alma n'Waman indicate pasture renewal, land clearing, burning agricul ture residues.

sures appear rather polarized along brush clearing (4 out of the 8 hamlets) and perimetral strips and pruning of trees ( 2 out of 8 for both), thus confirming the individual responses. This suggests that people are reluctant to fear the worst; culturally accepted precautions are considered adequate to provide protection from a risk that is badly perceived, probably because it is relatively infrequent (Beaver 2011).

\section{Use of fire}

Respondents use fire as a tool for stubble burning (27.5\% of respondents), burning for disposal of household waste (19\%), burning of weeds and agricultural residues, with $18 \%$ and $17 \%$, respectively. Other reasons for the use of fire (land clearing, brush clearing, renewal of ranges), received lower values $(4.9 \%, 4.6 \%, 4.3 \%$, respectively). Very low values characterize the activity of apiculture (fumigation of bee-hives) and last, restricted to only the hamlet of Tissira, the traditional use of fire for wild honey hunting (Fig. 4).

\section{How respondents learned to use fire and loss of its use}

The majority of respondents declare having learned to use fire from their fathers (50.8\%), followed by grandfathers $(30.7 \%)$ and then their mothers (14.6\%). This latter response confirms the matriarchal regime of hamlets in Kabilya and the importance of women's activity in agriculture (Grassof 2003).

For $69.2 \%$ of respondents, traditional knowledge of fire is still present, whereas for $30.8 \%$ traditional knowledge is not always there. Almost two thirds of respondents, in age classes 40 to 79 , gave a positive reply to the question, and $100 \%$ of more aged respondents, age class $>80$, confirmed this answer.

The main cause for which traditional knowledge of fire use is lost is related to its dangerousness, with a rate of $57.5 \%$, followed by the response that it is a tiring activity (29.5\%). Younger people who have abandoned working on the land, refuse this traditional knowledge, and clearly support $(62.2 \%)$ the idea that TEK is no longer present in the area.

\section{Conclusion}

The perception of the residents has been studied on the issues of wildfire risk, and the traditional use of fire. People have scarce awareness, tending to consider the phenomenon as decreasing, and illusorily perceive their hamlets to be well protected by preventive measures. The degree of concern about fire risk is moderate in Mizrana residents, with less than one third of them perceiving fire risk as a constant threat. Unapt or scarcely efficient prevention measures accompany this conviction.

Although traditional ecological knowledge in the use of fire was diffuse and qualified in the past, the survey group seems alien to this. The replies provided by the youngest underline this distance, when declaring that a motif of TEK disappearance is that it is tiring; the younger generation seems uninterested in agroforestry activities in relation to fire occurrence, and they implicitly expect protection and response from the State (Civil Protection, and Foresters) in case of a fire event. They do not blame themselves for failing to undertake adequate preventive measures and complain about the late arrival of firefighters, caused also by the distance from their headquarters.
Residents are unaware of the risks they are facing, or they are overly confident about it, and actually engage in hazardous behavior in the use of fire (for instance the disposal of domestic waste by fire is the cause of most wildfires).

Traditional prevention measures, evidenced by some respondents, are unfit to cope with a medium-high intensity fire, and the use of water as suppression agent (highly rated), further underlies a lack of awareness, as it is efficacious only on lowmedium intensity fires, not on the extreme fires that often ravage the country.

Lack of awareness is also indicated by a lack of compliance with law (as is the case of the perimetral ploughed strips around fields) and, in the opposite situation, in adopting measures which have a scarce or very scarce chance of containing a fire.

More than two thirds of the surveyed population think that their houses are not exposed to fire risk, because they are built with fire-resistant materials (concrete, brick, etc).

Passing from the individual to the collective lack of suitable behavior, we underline the inherent risk of living in the forest interface, without a collective effort to make these areas better protected and safer. Living in harm's way is accompanied by a discounting of the potential impacts of fires, so risk of loss of life or house destruction receives less attention.

Our survey indicates a lack of awareness of the inhabitants of these zones. More than just a misunderstanding of risk, respondents' cognitive limitation could be caused by "optimism bias": they tend to overestimate the likelihood of positive events, and underestimate the likelihood of negative events. 
Notwithstanding the relevant fire presence in the history of the area, the inhabitants appear to dismiss the evidence of hazardous conditions. They are probably induced by the infrequent occurrence of extreme events, and the fading of personal memory about them, which has nurtured a dangerous overconfidence on their fire suppression capabilities. This perception will make nearly impossible to implement efficacious prevention plans, or to cope with the increasing severity and frequency of wildfires which is projected to occur as a result of climate change.

Although living in two of the more fire prone towns in the most severely fire affected wilaya of Algeria, respondents' actions compound in the case of a wildfire disaster and aggravate potential losses, for instance unwisely using fire in severe fire weather conditions, or avoiding efficacious prevention measures.

Even though referred to a limited situation in Kabylia, this exploratory and qualitative study is the first to analyze fire risk perception in Algeria. Its findings suggest that a similar type of survey should be carried out at a wider scale, in order to explore how people really perceive fire threat, and how they behave on the ground, before mounting ambitious plans for a fire prevention program within the country.

\section{Acknowledgments}

We are very grateful to the respondents and foresters who accompanied us on the ground. We appreciate the time they dedicated to us and their remarkable attention and interest in responding to survey. We also thank the three anonymous reviewers for their insightful comments on the paper, as these comments led to an improvement of the work.

While remaining responsible for any errors in this paper, the authors would like to thank Dr. Robert Stacey, Northumberland Fire and Rescue Service, Cramlington (UK) for his patience and accessibility in reviewing the text and the numerous remarks he provided to improve it.

\section{References}

Alexandrian D, Esnault F, Calabri G (1999). Forest fires in the Mediterranean area. Unasylva 197 (50): 35-41. [online] URL: http://www.fao.org/ docrep/x1880e/x1880e07.htm

Bassi S, Kettunen M (2008). Forest fires: causes and contributing factors in Europe. Study IP/A/ENVI/ST/2007-15, PE 401.003, Policy Department Economic and Scientific Policy, European Parliament, Brussels, Belgium, pp. 49. [online] URL: http://www.europarl.europa.eu/ thinktank/en/document.html?reference=IPOLENVI_ET(2008)401003

Beaver A (2011). Wildland urban intermix, disaster by design. In: Proceedings of the " 5 th International Wildland Fire Conference". Sun City, Pilanesberg National Park (South Africa) 9-13 May 2011, pp. 1-9.

Bekdouche F, Derridj A, Krouchi F (2008). Evolu- tion après feu de la composition floristique de la subéraie de Mizrana (Tizi Ouzou, Algérie) [After fire evolution in the floristic composition of the Mizrana forest (Tizi Ouzou, Algeria)]. Revue Sciences and Technologies, série C 28: 19-29. [in French]

Belkaid H (2016). Analyse spatiale et environnementale du risque d'incendie de forêt en Algérie: cas de la Kabylie maritime [Spatial and environmental analysis of forest fire risk in $\mathrm{Al}$ geria: the case of Kabylie maritime]. Thèse de Doctorat en Géographie, Université de Nice Sophia Antipolis, France, pp. 255. [in French] [online] URL: http://tel.archives-ouvertes.fr/tel01355757

Berger A, Kousky C, Zeckhauser R (2008). Obstacles to clear thinking about natural disasters: five lessons for policy. In: "Risking House and Home: Disasters, Cities, Public Policy. Berkeley" (Quigley JM, Rosenthal LA eds). Berkeley Public Policy Press, CA, USA, pp. 73-94. [online] URL: http://sites.hks.harvard.edu/fs/rzeckhau/ natural_disasters.pdf

Berkes F, Colding J, Folke C (2000). Rediscovery of traditional ecological knowledge as adaptive management. Ecological Applications 10: 12511262. - doi: 10.1890/1051-0761(2000)010[1251: ROTEKA]2.o.CO;2

Cardil A, Eastaugh CS, Molina DM (2014). Extreme temperature conditions and wildland fires in Spain. Theoretical and Applied Climatology 122 (1-2): 219-228. - doi: 10.1007/s00704-0141295-8

Catry FX, Damasceno P, Silva JS, Galante M, Moreira $F$ (2007). Spatial distribution patterns of wildfire ignitions in Portugal. In: Proceedings of the " $4^{\text {th }}$ International Wildland Fire Conference". Seville (Spain) 13-17 May 2007, pp. 8-17. [online] URL: http://sites.google.com/site/fca try2/DISSERTAOMESTRADO-ISEGI.pdf\#page $=16$ Chuvieco E, Salas FJ, Carvacho L, Rodríguez-Silva F (1999). Integrated fire risk mapping. In: "Remote Sensing of Large Wildfires in the European Mediterranean Basin" (Chuvieco E ed). Springer-Verlag, Berlin, Germany, pp. 61-84.

Corona P, Ascoli D, Barbati A, Bovio G, Colangelo G, Elia M, Garfi V, lovino F, Lafortezza R, Leone $\mathrm{V}$, Lovreglio R, Marchetti M, Marchi E, Menguzzato G, Nocentini S, Picchio R, Portoghesi L, Puletti N, Sanesi G, Chianucci F (2015). Integrated forest management to prevent wildfires under Mediterranean environments. Annals of Silvicultural Research 39 (1): 1-22. - doi: 10.128 99/asr-946

De Montgolfier J (1989). Protection des forêts contre les incendies. Guide technique du forestier méditerranéen français [National Report of Algeria on the implementation of the Convention to Combat Desertification]. Ed. CEMAGREF, Division des Techniques Forestières Méditerranéennes, Aix-en-Provence, France, pp. 116. [in French]

DGF (2004). Rapport national de l'Algérie sur la mise en oeuvre de la convention de lutte contre la désertification [National Report of Algeria on the implementation of the Convention to Combat Desertification]. Direction Générale des Forêts - DGF, Algérie, pp. 35. [in French] Duguy B, Paula S, Pausa JC, Alloza JA, Gimeno T, Vallejo RV (2013). Chapter 6. Effects of climate and extreme events on wildfire regime and their ecological impacts. In: "Regional Assessment of Climate Change in the Mediterranean: Volume 2: Agriculture, Forests and Ecosystem Services and People" (Navarra A, Tubiana L eds). Advances in Global Change Research 51, Springer Science+Business Media, Dordrecht, Netherlands, pp. 102-134. - doi: 10.1007/978-94007-5772-1_6

European Commission (2015). Forest fires in Europe, Middle East and North Africa 2014. EU Publication no. EUR 27400 EN, Publications Office of the European Union, Luxembourg, pp. 107. - doi: 10.2788/224527

FAO (2006). Global forest resources assessment 2005 - Report on fires in the Mediterranean region. Fire Management Working Paper 8, FAO, Rome, Italy. [online] URL: http://www. fao.org/docrep/009/a0969e/ao969eoo.htm

Ford C (2008). Reforestation, landscape conservation, and the anxieties of empire in French colonial Algeria. American Historical Review 113 (2): 341-362. - doi: 10.1086/ahr.113.2.341

Ganteaume A, Camia A, Jappiot M, San MiguelAyanz J, Long-Fournel M, Lampin C (2013). A review of the main driving factors of forest fire ignition over Europe. Environmental Management 51 (3): 651-662. - doi: 10.1007/s00267-0129961-z

Gonzalez A (2007). The housing boom and forest fires. SSRN Web site, pp. 29. - doi: 10.2139/ssrn. 1107120

Gouveia CM, Trigo RM, Beguería S, Vicente-Serrano SM (2016). Drought impacts on vegetation activity in the Mediterranean region: an assessment using remote sensing data and multiscale drought indicator. Global and Planetary Change 151: 15-27. - doi: 10.1016/j.gloplacha.2016. 06.011

Grassof M (2003). The central position of women in the life of the Berbers of Northern Africa exemplified by the Kabyles. In: Proceedings of the " 2 nd World Congress on Matriarchal Studies". Austin (TX, USA) 1-2 Oct 2005, pp. 1. [online] URL: http://www.second-congressmatriarchal-studies.com/grasshoff.html

Guettouche MS, Derias A, Boutiba $M$, Bounif $M$, Guendouz M, Boudella A (2011). A fire risk modelling and spatialization by GIS. Journal of Geographic Information System 3: 254-265. - doi: 10.4236/jgis.2011.33022

Hamel H (2016). Contribution à l'analyse de la dynamique post-incendie de la série de chêne liège (Quercus suber) de la forêt domaniale de Mizrana (Wilaya de Tizi-Ouzou) [Contribution to the analysis of post-fire dynamics of the cork oak series (Quercus suber) in the Mizrana National Forest (Tizi-Ouzou Wilaya)]. Thesis of Magister en Science Agronomique, Université Mouloud Mammeri, Tizi-Ouzou, Algeria, pp. 93. [in French]

Houde N (2007). The six faces of traditional ecological knowledge: challenges and opportunities for Canadian co-management arrangements. Ecology and Society 12 (2): 34. - doi: 10.5751/ES-02270-120234

Kousky C, Luttmer EFP, Zeckhauser R (2006). Private investment and government protection. Journal of Risk and Uncertainty 33 (1-2): 73-100. [online] URL: http://users.nber.org/ luttmer/in vestmentprotection.pdf

Lampin-Maillet C, Jappiot M, Long M, Bouillon C, 
Morge D, Ferrier JP (2010). Mapping wildlandurban interfaces at large scales integrating housing density and vegetation aggregation for fire prevention in the South of France. Journal of Environmental Management 91 (3): 732741. - doi: 10.1016/j.jenvman.2009.10.001

Langer ER, McGee T (2017). Wildfire risk awareness and prevention by predominantly Maori rural residents, Karikari Peninsula, Aotearoa New Zealand. International Journal of Wildland Fire 26: 820-828. - doi: 10.1071/WF16133

Meddour R (1992). Régénération naturelle de Cedrus atlantica Man. et de divers pins après incendie dans l'arboretum de Meurdja (Algérie) [After fire natural regeneration of Cedrus atlantica Man. and various pines in the arboretum of Meurdja (Algeria)]. Foret Méditerranéenne 13 (4): 275-287. - [in French] [online] URL: http://fr. scribd.com/document/101746441/

Meddour-Sahar O, Bouisset C (2013). Les grands incendies de forêt en Algérie: problème humain et politiques publiques de gestion des risques [Large wildfires in Algeria: human issues and public policies towards risk management]. Méditerranée 121: 33-40. - [in French] - doi: 10.400 o/mediterranee.6827

Meddour-Sahar O, Derridj A (2010). Le risque d'incendie de forêt: évaluation et cartographie. Le cas de la wilaya de Tizi Ouzou, Algérie (période 1986-2005) [Forest fire risk: Assessment and cartography. The case of Tizi Ouzou department, Algeria (period 1986-2005)]. Sécheresse 21 (3): 187-195. [in French]

Meddour-Sahar O (2014). Les feux de forêt en Algérie: analyse du risque, étude des causes, évaluation du dispositif de défense et des politiques de gestion [Motifs of forest fires in Algeria: comparative experts' knowledge of Civil Protection and Forestry Service by Delphi analysis]. Thèse de Doctorat en Sciences Agronomiques, Université Mouloud Mammeri, Tizi Ouzou, Algeria, pp. 256. [in French]

Meddour-Sahar O (2015). Wildfires in Algeria: problems and challenges. iForest - Biogeosciences and Forestry (8): 818-826. - doi: 10.3832/ifor1279-007

Meddour-Sahar O, Lovreglio R, Meddour R, Leone V, Derridj A (2013a). Fire and people in three rural communities in Kabylia (Algeria): results of a survey. Open Journal of Forestry 3: 30-40. - doi: 10.4236/ojf.2013.31006

Meddour-Sahar O, Meddour R, Leone V, Lovreglio R, Derridj A (2013b). Analysis of forest fires causes and their motivations in North Algeria: the Delphi method. iForest - Biogeosciences and Forestry 6 (4): 247-254. - doi: 10.3832/iforoog8-006

Ouelmouhoub S, Benhouhou S (2007). Evolution floristique des subéraies incendiées dans la région d'El Kala (Nord-est algérien) [Post fire floristic evolution of cork-oak forests in the El Kala region (northeastern Algeria)]. Ecologie Méditerranéenne 33: 85-94. [in French]

Peyre S (2001). L'incendie, désastre ou opportunité? L'exemple des Pyrénées Orientales [Fire, disaster or opportunity? The example of the Eastern Pyrenees]. Forêt Méditerranéenne 20: 194-199. [in French]

Pswarayi-Riddihough IZ (2002). Forestry in the Middle East and North Africa - An implementa- tion review. Technical Paper no. 521, Forestry Series, World Bank, Washington, DC, USA, pp. 66. [online] URL: http://documents.worldbank. org/curated/en/823521467989973007/pdf/multi opage.pdf

Rashid GH (1987). Effects of fire on soil carbon and nitrogen in a Mediterranean oak forest of Algeria. Plant and Soil 103 (1): 89-93. - doi: 10.1007/BF02370672

Slimani S, Touchan R, Derridj A, Kherchouche D, Gutiérrez E (2014). Fire history of Atlas cedar (Cedrus atlantica Manetti) in Mount Chélia, Northern Algeria. Journal of Arid Environments 104: 116-123. - doi: 10.1016/j.jaridenv.2014.02.008 USFWS (2017). Traditional ecological knowledge for application by service scientist. US Fish and Wildlife Service, Washington, DC, USA, pp. 5. [online] URL: http://www.fws.gov/nativeame rican/pdf/tek-fact-sheet.pdf

Usher PJ (2000). Traditional ecological knowledge in environmental assessment and management. Arctic 53 (2): 183-193. [online] URL: http://www.jstor.org/stable/40512207

Velez R (2000). La prevencion [Prevention]. In: "La defensa contra incendios forestales fundamentos y experiencias" (García-Brage A ed). McGraw-Hill/Interamericana de Espana, Madrid, Spain, pp. 1320. [in Spanish]

\section{Supplementary Material}

Appendix 1 - Survey questionnaire: the perception of forest fire risk in Kabylia.

Link: Sahar_2546@supplo01.pdf 